\title{
3D Modelling of an Important Symbol of the Orthodox Wooden Churches - The Imperial Gates
}

\author{
Radu Moraru \\ Faculty of Fine Arts \\ University of Art and Design \\ Piața Unirii 31, 400098 \\ Cluj-Napoca, Romania \\ radu.moraru@uad.ro
}

\author{
Oana Gui \\ Communication and IT Centre \\ University of Art and Design \\ Piața Unirii 31, 400098 \\ Cluj-Napoca, Romania \\ oana.gui@uad.ro
}

\author{
Pr. Ioan Chirilă \\ Faculty of Orthodox Theology \\ „Babeș Bolyai” University \\ Str. M. Kogălniceanu nr.1, 400084 \\ Cluj-Napoca, Romania \\ ioanchirila@yahoo.com
}

\begin{abstract}
The paper presents an on-going process to digitally reconstruct the Imperial Gates of the old Romanian orthodox churches scattered on a large geographical area in Transylvania. Due to the locations of the churches and to the indestructible character of the iconostasis, the 3D scanning had to be contact-free. The actual chosen method is a low cost method, based upon free software that allows scanning of three-dimensional objects and does not rely on specific hardware. The intended final result is to provide a collection of 3D models of the Imperial Gates that could be further integrated in other projects of the Art and Design University and of the Faculty of Orthodox Theology, “Babeş Bolyai” University, from Cluj-Napoca, Romania.
\end{abstract}

Imperial Gates. 3D scanning. Cultural heritage. Orthodox wooden churches.

\section{INTRODUCTION}

This paper intends to present the ongoing process of 3D scanning and modelling of the Imperial Gates from wooden churches in Transylvania. It is a joint initiative of the Sculpture Department of the Art and Design University and of the Faculty of Orthodox Theology, "Babeş Bolyai" University from ClujNapoca, Romania.

In many instances, the churches we are speaking about occur in isolated, aging rural communities, Transylvania remaining one of the few European territories where hundreds of wooden churches are still preserved and in most cases still in service. Preserving by digital means any part of those wooden churches, such as the Imperial Gates, is thus an important part in the process of disseminating our cultural heritage. Although there is interest in the mural paintings and also in the vernacular architecture of the wooden churches, little has been done until now to reveal the artistic value of the sculptural elements, among which the Imperial Gates hold an important place.

Due to the locations of the churches and to the indestructible character of the iconostasis, the 3D scanning had to be contact-free. The actual chosen method is a low cost method, based upon free software that allows scanning of three-dimensional objects, a pure software solution that does not rely on specific hardware. The only hardware requirements are a simple commercial hand-held laser and a camera with WDM support.

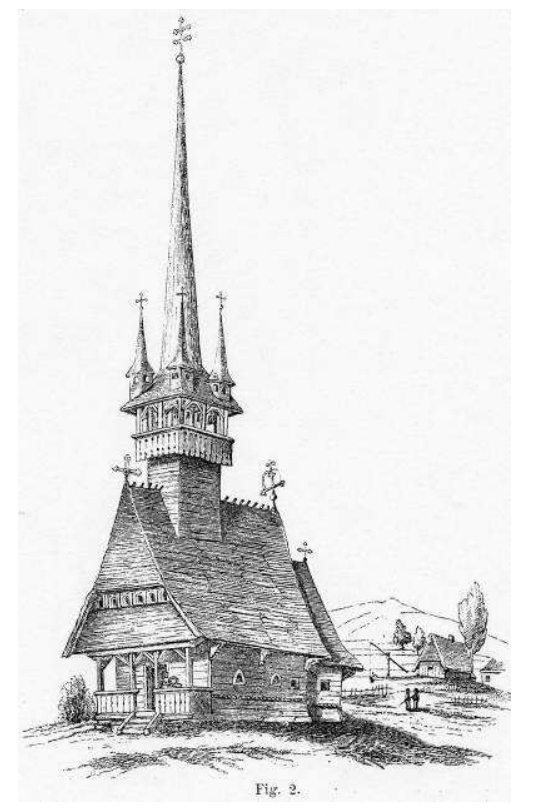

Figure 1: First image of a wooden church from Transylvania (Roșiori), published in 1866 (Haas \& Schulcz, 1886)

The intended final result is to provide a collection of 3D models of the Imperial Gates that could be 
further integrated in other projects of the Art and Design University and of the Faculty of Orthodox Theology, "Babeş Bolyai" University, from ClujNapoca, Romania.

Our endeavour is a small step to protect and disseminate a fragile cultural heritage that is vanishing at an alarming pace, due to multiple causes: increased illicit traffic of art works, lack of education of certain social segments, temptation of an immediate gain, insufficient infrastructure for the protection of the cultural heritage, insufficient involvement of the local authorities, faced with the problems of an ageing rural population. Civil society is still unused to react or to solidarize at a cause and the nongovernmental organisations have a reduced number of members and a limited capacity of influence.

\section{THE IMPERIAL GATES}

Parts of an indestructible component of any orthodox church, namely the iconostasis, The Imperial Gates represent an important symbol in our cultural heritage.

\subsection{Wooden churches from Romania, a historic perspective}

Small wooden churches (more than 1440 in Romania and more than 650 in Transylvania only), dating back to 16th-19th century, hidden in places that virtually nobody heard of, hide art treasures with a significant religious and important artistic value that allows us to decipher the lay perspective on natural and supernatural world. During ages, the foreign conquerors of Transylvania didn't allow the orthodox peasants to build stone or brick churches that could last over centuries (Godea \& Medeleanu, 2009). Paradoxically, the small wooden churches they were allowed to build proved over centuries to become a long lasting cultural heritage of this part of the world (Cîmpian, 2002a \& 2001b).

A defining characteristic of the rural Transylvanian churches, as opposed to the major cathedrals in urban spaces, is the scaling of their vernacular architecture according to the human scale. By doing this they become "an edifice that in many aspects seems to keep almost nothing from the characteristics of the House of God. Here the old Christian church transformed itself in an intimate place for prayers, as modest as the house of the peasants itself" (Pănoiu, 1977).

The oldest wooden church in Transylvania can be found in Lupşa, Alba County, and dates back to 1429 , but most of them were build between the 17 th and 19th century. The first initiative regarding an inventory of the Transylvanian wooden churches belonged to the Central Committee of the Historical Monuments from Vienna, in 1857 (Haas \& Schulcz, 1866). A complete inventory can be found at present on the site of the Institute for Cultural
Memory, Bucharest (http://cimec.ro). Since 1999, eight wooden churches were listed by UNESCO on its World Heritage List: Budești (1643), Desești (1770), Bârsana (1720), Poienile Izei (1604), leud (beginning of 17th century), Șurdești (1767), Plopiș (1798) and Rogoz (1663) (http://whc.unesco.org/en/list/904).

\subsection{The symbol of the Imperial Gates}

The theme of the door/gate appears frequently in the scriptural texts, in the descriptive context of the garden of Eden, together with the account of driving man out of Paradise (Genesis 3,24 ), and although in this case the concept is "way/ path" derek et hahaiim, both the Judaic and the Christian exegesis interprets the place where the Cherubim is placed as the gate of Eden. The next episode is that of the angelophany at Bethel (Genesis 28, 17), when Jacob says: "How awesome is this place! This is none other than the house of God; this is the gate of heaven" - eik ze ki im-beit elohim ve $z e$ şaar haşamaim. The image of the gate appears many times in the prophetic oracles, for example in the book of the prophet Ezekiel 44, 2-3: "this gate is to remain shut..." - haşaar haze magur ihie; according to the patristic exegesis, this theme has a strong typological-mariological nuance: the gate announces the Virgin Mary, and by this, the possibility of entering into the New Testament, where, in the person of our Saviour, the two concepts (way/path and door/gate) coexists, is open to us: "I am the way..." (John 14, 6), "I am the gate" (John 10, 9) or even the assertion of Archdeacon Stephen: "I see heaven open" (Acts 7, 56).

The liturgical theology acknowledges the fact that there is a relationship of complementarity/ continuity between the Judaic and the Christian worship. The sacred space has similar structures and meanings. The theme of the door is present in the description of the Temple/ the Church (Exodus 25; III Kings 6; Ezekiel 41-42). What is different is the number: in the case of the Temple there were two doors, here three, because the foundation of the Christian Church is the Holy Trinity. The

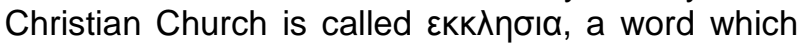
comes from the Greek $\varepsilon \kappa \kappa a \lambda \varepsilon \dot{\omega}$ - call forth, summon forth, because the Church is the community of those called to Christ, who, through the Church, live in Christ and in heaven - regnum Deil Basileia tou Theou/ Reich Gottes. Clement of Rome says: According to His will, God Himself pointed to the place where these holy services (sacrifices) must be held and to those who must accomplish them (To the Corinthians 1, 40). The Fathers of the Church say about this place that it is a spiritual foreshadowing of the divine Logos Himself, in which the images of all creatures are contained even before the creation, and after creation and the salvation brought by Christ, the creatures themselves gathered together in Him, in what is a visible appearance of the unseen Church, 
are contained too (Eusebius of Caesarea, Church History X, 4, 21). Father Dumitru Staniloae (Stăniloae, 2000 \& 2004), says that "the heavenly pattern of the church is made primarily according to the soul which, being corrupted by sin, is renewed by being stamped by its divine pattern, the hypostatic Logos (X, 54). We could say that the entire man is an image of the Logos or an image of the heavenly temple which, through man, spreads throughout the world as the Jerusalem from above. Thus, the Church appears not only as a space, but also as a concrete environment of transcending. Its structural-architectonical and iconographical structure is a continuous call, a divine lesson/ a continuous epiphany through which one enters heaven, but by being humble.

The ecclesiastic space in Transylvania offers such an image. Until you reach the union with the Eucharistic Christ you have to humbly enter three gates: the gate from the entrance in Church's yard, a low gate which represents the entrance into the narrow path (it is the gate of Paradise); the gate of the Church, equally low as the first one, it is the gate of heaven, and the imperial gates, which open the entrance into the glory of God (the gate Virgin, the gate Christ), open de depths of heaven and Christ come among/ in us.

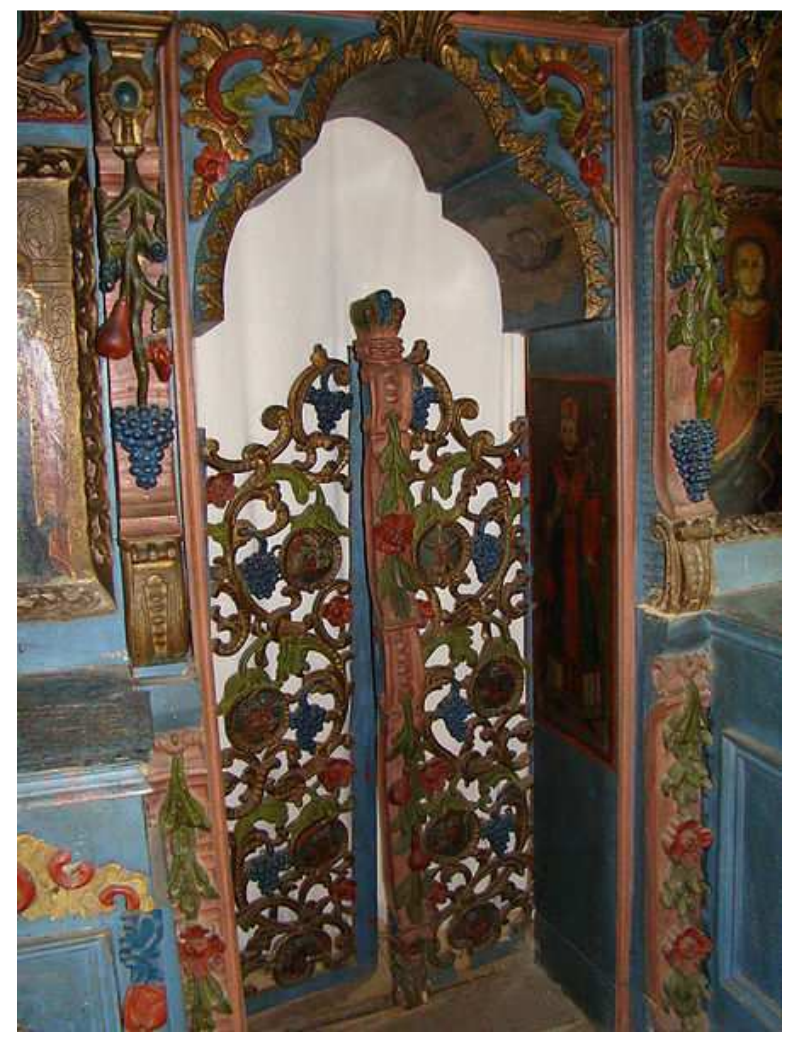

Figure 2: Imperial gates from the church of Dumbrava, Maramureş county, sec. XVIII

The books containing the rules for the Byzantine iconography assign for the imperial gates the icon of the Annunciation, as an inaugural moment of the
The iconostas is a transparent wall which, when it comes to prayer, receives and amplifies the prayer of the heart: "Lord Jesus Christ, Son of God, have mercy on us, sinners, and protect us with your grace". Under the pressure of this prayer, the imperial gates largely open in order that we may see the heaven. The liturgical commentaries explain the symbolism of the doors as an image of Christ through whom we may see the heaven open (John 1, 51), because "I am the gate" (John 10, 7). The liturgical dynamics specific to the Eastern tradition implies the frequent coming out of the priest into the nave, entering among the people and being surrounded by the believers according to a natural understanding of the existing communion into the Church. This shows, on one side, that the position and the function of the priest is not one of authority upon the people, but of expressing and achieving the transcendence, the coming of God among us. It is not the human being the one who enters the mysterious space/ place of divinity - the altar -, but it is God who descends and comes through what is symbolically expressed by (and on) the imperial gates, through the gate-Christ (John $10,7)$.

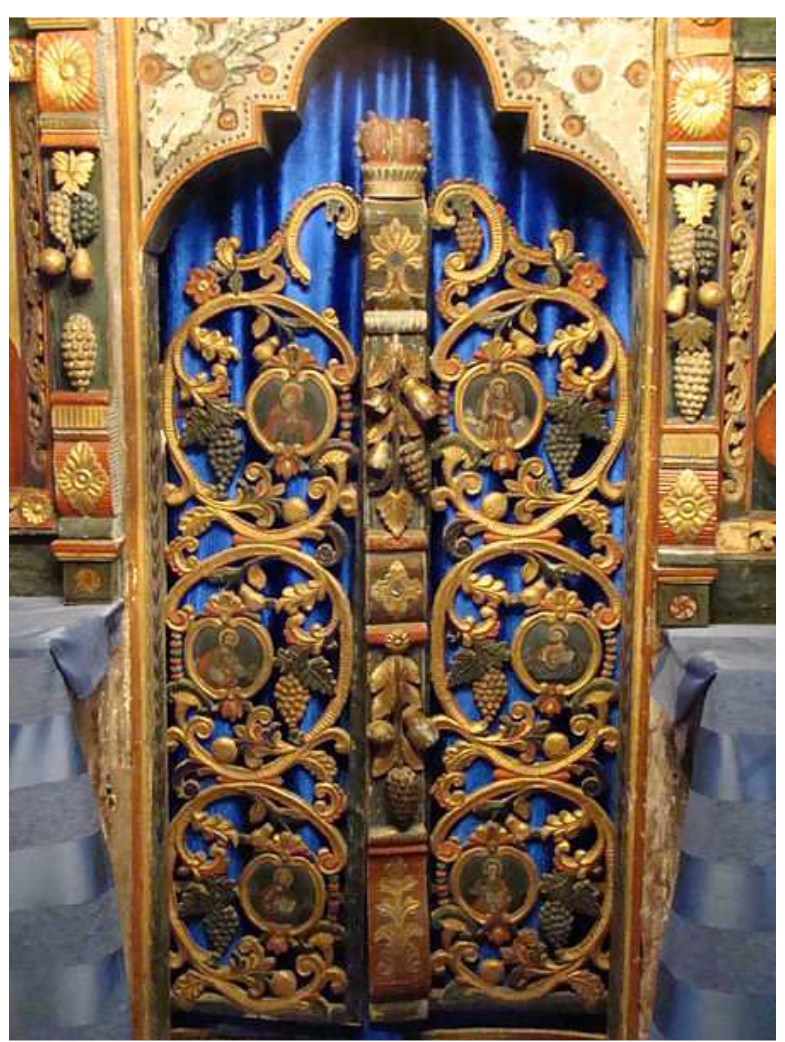

Figure 3: Imperial gates from the church of Poșta, Maramureş county, 1675

redemption work done by Christ, the one who opens the gates of heaven. Christ is also symbolically represented on these imperial gates, 
under the image of the vine: "I am the vine, you are the branches" (John 15, 5) and under the image of his fruit which bestows life, that is His blood: "This is my blood" (Matthew 26, 28). The image of wine has also an immediate eschatological valence, announcing the fulfillment of the Heavens' Kingdom: "...I will not drink from this fruit of the vine from now on until that day when I drink it new with you in my Father's kingdom" (Matthew 26, 29). Therefore, the imperial gates are the way through which God descends, through which He enters in communion with his creature, through Christ-the Way (John 14, 6), thus realizing the relation of communion now, a relation of communion which has a prophetic dimension, since the fulfillment of this communion is proper to the eternity with and within God.

The imperial gates open towards the altar, the visible space in which the Liturgy is celebrated, but in which heavens and earth are reunited in the sound of the eternal doxology. Thus, although limited in extension, the altar makes the transcending of time and space possible; here other conditions of existence are effective, it is a place of the unseen, of detachment from the world, an extramundane space. The altar is a distinct space which always remains inaccessible and marked by transcendentality. The whole altar is heaven. According to the cosmological interpretation of Saint Simeon, the altar is a symbol of heaven, and the rest of the Church symbolizes the earth. The necessity of separating the altar is render evident, in order that this meaning might be properly underlined: "it cannot be done except by using elements susceptible of being perceived in two ways: if it would be only about spiritual realities, then these would become inaccessible to our weakness, and by that the conscience would be deprived of their benefic effect. If, on the contrary, it would be confined to the world of the seen, then the limit of the unseen could be no longer determined or found".

But the heaven cannot be delimited from earth except through visible witnesses of the unseen world, through living symbols of each other's fusion. This is why we say that the iconographic representations which enrich the iconostas are windows open to eternity and, simultaneously, are windows from eternity towards history, through which eternity descends in time. The fruit of the Christian artistic creation is, in fact, the sign of passing from one sphere to another, from one world to another. It is the symbolical embodiment of all the soul contemplates within the spiritual experience. Carrying with himself the rich dowry of what was revealed to him, the artist lays down in his work of art experiences of mystical life and through the image make them to descend in the earthly world in order to support the progress of the other towards the heavenly ones. The image is not only a graphic representation, but the iconic representation is an ontological manifestation, in the say as the tradition of the Church understood the presence of the image of God in man, as an ontological gift, while the likeness expresses a potentiality, the power of man of shaping himself according to the image of God, so that the face might be the expression of the clarity of his spiritual structure. But until then the face is light mixed with darkness, and, as the sin takes hold of the soul, of someone's life, his face ceases to be the window through which the light of God shines (Florovski, 1994). Or, the icon of the saints found on the iconostas is precisely this: the image of those who understood to be windows, who achieved in themselves this brightness of face as expression of fulfilling the image of God. The saints belong simultaneously to those two worlds and they have in themselves the present and the future life, giving testimony to this world of the mysterious working of God. Therefore, the iconostas must not be considered an obstacle, but a material representation of a heavenly vision: saints, angels, the Mother of God and our Saviour Jesus Christ, these are the witness who announce what is to be found on the other side of the body. This is why we would like to call the iconostas "announcing", or opening of the mysteries of the altar - heaven, and the imperial gates the Annunciation made to everybody. Through the icon one may transcend the Cartesian limits and enter into an ontological relation with the prototype himself: "then and only then the tangible sign fills up with the saps of life" (Florovski, 1994). It is not about a simple representation, but about a way towards the accomplishment of a relation with the energy itself of the Being.

Thus the project aims at restoring these bridges of transcending, but their restoration will determine a restoration of our way of relating to the transcendent.

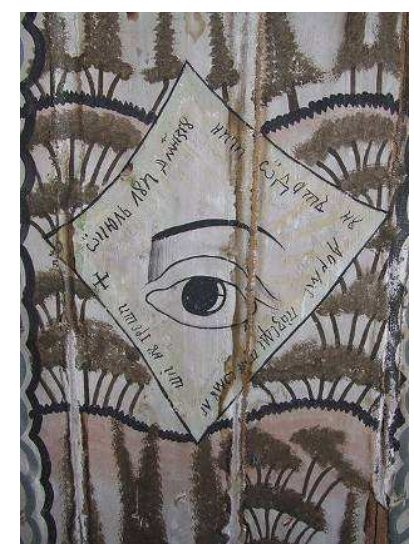

Figure 4: The Eye of God, Găbud, Mureș (1776) 


\subsection{Deciphering the lay perspective}

As mentioned before, the path to transcendental passes, in the Romanian orthodox tradition, through three gates, through three levels of access: the entrance into the churchyard, the portal and, accessible only to the priests, the imperial gates that separate the altar. Due to the small size of the Transylvanian wooden churches, the imperial gates tend to take on a greater significance in the eyes of the believers.

The same way the space of the small wooden churches models and prepares the soul of the worshiper, the simple life of the last one influences the architectonical and iconographical structure of the wooden churches, allowing us to decipher the lay perspective upon the sacred space. It is the perspective of a long line of generations that shaped the rural space of Transylvania: "Generations of peasants have moulded these hillsides into a patchwork of bite sized farming strips. While the land has been shaped by its people, it has returned the favour by anchoring its peasants in their ancestral ways. The land demands their care but returns its bounty, generation after generation, stretching back before history" (McLaughlin, 2002).

It is the perspective of people that still live each day "according to the weather, maintaining constant contact with the rhythms within which humanity evolved" (McLaughlin, 2001). From their perspective the Eye of God is watching us with serenity from the ceiling of the church, angels are loaded with eyes, enough to watch us all, and God is represented at the base of the imperial gate resting on the $7^{\text {th }}$ day. This region is unique for the way it has preserved its way of life. For fifty years under communist rule, a few valleys escaped collectivization because of their hilly landscape. After 1989 preservation continued due to pervasive impoverishment which slows the advancement of modernity. But nothing will stand still forever.

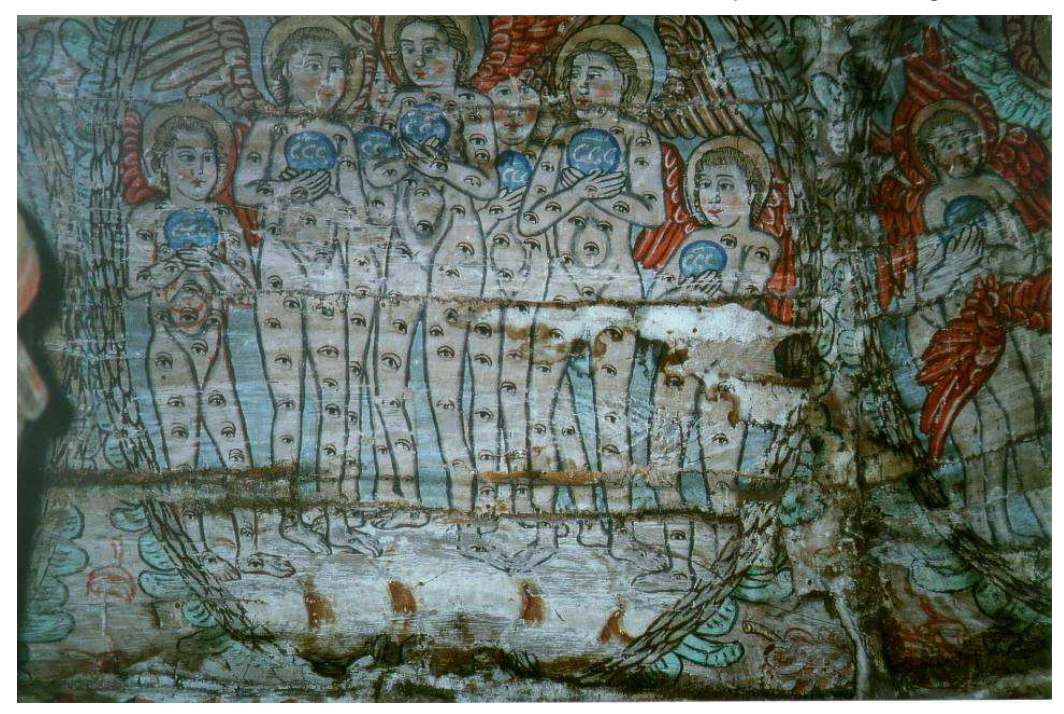

Figure 5: Detail of mural painting. Bîrsana, Maramureş (1711). Enlisted on the UNESCO World Heritage. Foto: Rodica Alămoreanu

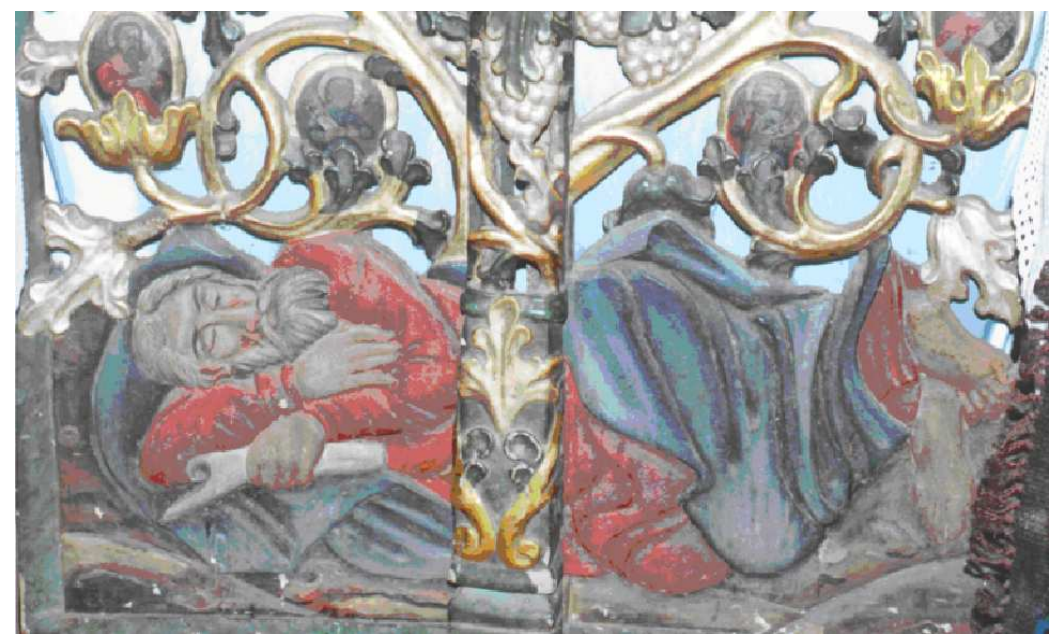

Figure 6: God resting on The $7^{\text {th }}$ Day. Detail of the Imperial Gates. The Church of the Holy Parasceve, Poienile Izei, one of the oldest wooden church of Maramureş (1604). Enlisted on the UNESCO World Heritage. 


\section{THE SCULPTURAL ELEMENTS}

In an attempt of foray in the world of forms that can decipher the lay way of knowing the natural and supernatural world, this paper wants to give a focalized image on the symbol of the imperial gates within the orthodox churches' altars. The imperial gates, carved in lime or oak wood, through their vegetable nature represent the gates of the paradise on Earth. In the Gospel the gates are identified with Jesus Himself, who says: "I am the gate, if somebody will pass through Me, it will be saved". The gates' place appears as a transverse section through the seen and unseen heart of the Holy Cross.

The wooden upper knitting of the imperial gates follows, most of the time, the shape of a heart with its "pick" orientated towards the sky, as a cup put upside down and from where grace flows down to the creation. The top of the heart and its orientation towards the sky sustains the icon where the figure of God is painted. The imperial gates in their functionality between the altar and the rest of the church are opened and closed in a horizontal level describing the ritual "exits" and "entrances".

The ornaments and the symbolism of the carved forms translate general archetypes of the humanity. We can only take our bench-marks from the known nature. We represent ourselves the other nature, the intuited one, through means which are accessible to the common sense. Within the physical space, our conscience needs to mark this delimitation. The gate of passing from the physical to the metaphysical exists only in our mind and senses.

We decorate it with the symbols - bench-marks that we can associate with our material existence on Earth. We try to understand the metaphysical through physical bench-marks that can have values of symbols: the tree of life, the grape, the wheaten ear, etc. For the religious man nature is loaded with sacred being present all around us. The orthodox churches' ornaments are full of life and nature. Because of this it has its own authenticity. The translation of the "ageless" in a perceptive material form is made by the symbols which are mainly vegetable. A subconscious mind associates the permanent life with the luxurious vegetation. Therefore we can decipher the vegetable richness as an unlimited source of creation. The symbol of the "Tree of life" can be deciphered as a metaphor of the endlessness in time and space. The vegetation, the nature carrying the seed of eternity is ubiquitous within the Orthodox Church. Connected with the topic presented here, at a closer look we see that all this vegetable richness of the wooden decoration is concentrated on the imperial gates, a magical space that marks the passage spot both physical and metaphysical.
From the beginnings our conscious and subconscious needed marks and it found these marks according to the perceptional-visual data, such as the plain's horizontal, the tree's vertical and its ramification, the sun's round form, the mystery of the moon, the sea's calling, the stars' movement, the sky's blue, the fire's red, etc. All of these, simple perceptions, are generators of forms connected with our conception about the world and about our place in it; there are also generators of symbols which we use to operate in order to establish the needed conceptual marks, in order to find ourselves within our own person and within the immensity of the universe.

The first marks of the civilizing man where the axial coordinates, as a first mean of orientation in the space: what was found on the horizontal could be measured, therefore researched and known. But when the man looked up, he realized that the vertical is beyond the control of the measures used in the horizontal world. Maybe this was the moment when the consciousness woke up. Not being able to determine the distance to the stars, he understood that there is God.

The moment us, artists, scientists, theologians and philosophers discover the significance of this transcendental border, the gate becomes a sacred doorway which we can pass through using the power of the mind and faith. The gate's physical form just transposes the virtual image loaded with symbols which direct the perception towards the archaic myths of the humanity: the day and the night, the 4 seasons, the vegetation and the rhythm of life. Above all these there's only intuition.

Watching the ornaments carved on the orthodox rood screen we can observe the joy of celebrating life beyond a determined time. The predominant vegetable element reveals, in fact, the feeling of having faith in perpetuity. The seed of life is seen through these vegetable forms that symbolize the resurrection and the eternal life.

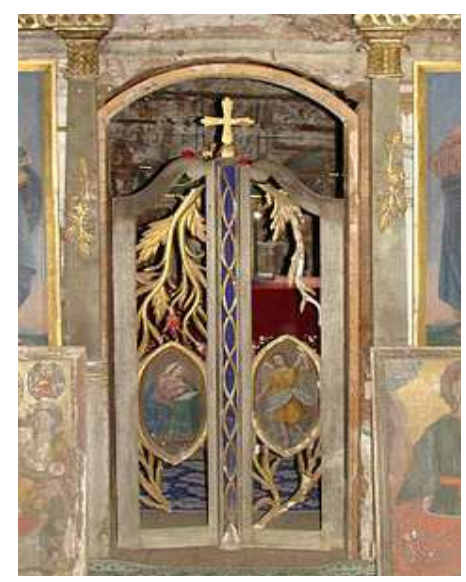

Figure 7: Deteriorated imperial gate, Vălenii Șomcutei, Maramureș, sec.XVII 


\section{RESEARCH METHODOLOGY}

Our research is focused on the sculptural elements of the imperial gates from Transylvanian wooden churches registered in the national list of historic monuments. The research methodology is currently carried on two planes:

- Establishing a procedure for selecting the churches that are significant to our research;

- Establishing the proper 3D scanning and modelling procedure.

For the selection procedure, extensive documentation work still needs to be done. Starting from the updated list provided by CIMEC the first step was to eliminate from the list the churches that no longer exist or are too damaged. The rate at which the wooden churches disappear is alarming (e. g. in Alba county at least $7.5 \%$ from the above mentioned churches vanished). Paradoxically, the best preserved ones are those who are still in use. But the depopulation of the rural area reduces their number year after year. Some of the inactive churches were saved by being included in open air village museums. or at least valuable artistic artefacts could be saved sometimes and moved to museums. In some cases the imperial gates were damaged and replaced with simple doors or even curtains, without any artistic or symbolic value. The documentation work is based on the existing bibliography (Babos, 2004; Godea \& Medeleanu, 2009; Nistor, 1983), but also on information from different other sources: on site visits, information posted on institutions' sites (Mitrofan \& Ghiță, 2008] and even Wikipedia.

\subsection{D scanning}

Establishing the proper 3D scanning and modelling procedure is made easier by the fact that the scanned objects have, within limits, similar geometry and dimensions. The basic idea is to use a real-time self-calibration of a hand-held laser plane, which is based on a simple analysis of the laser stripes in the camera images.

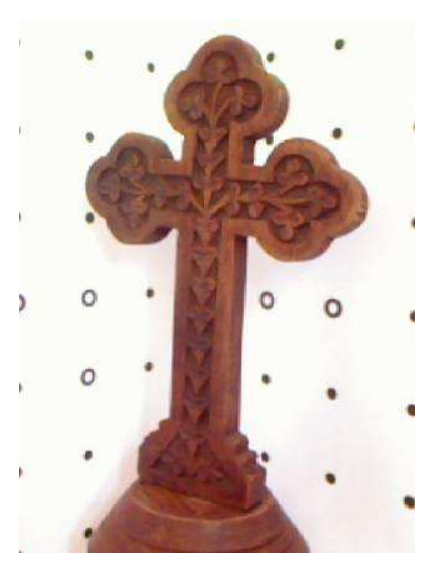

a. Image grabbed for texture

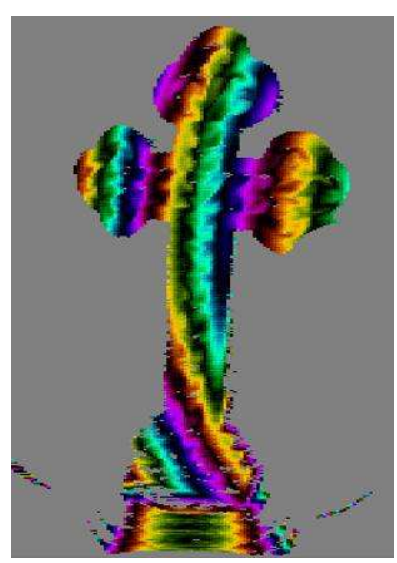

b. Depth image

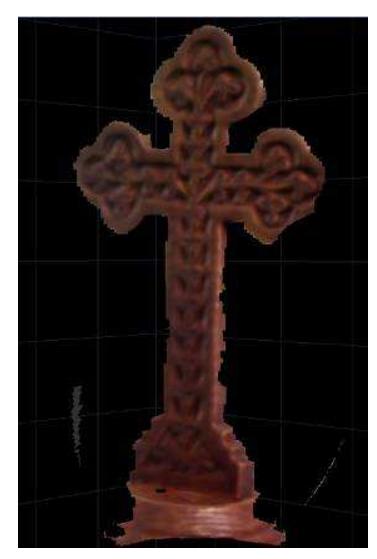

c. 3D reconstruction

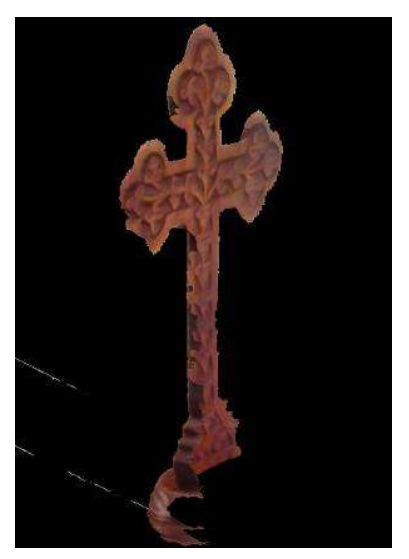

d. Rotated 3D reconstruction

Figure 8: Detail from a test image (cross from Bârsana), taken with a HD webcam, 640x400, 30 fps, $24 R G B$. The object is aprox. $16 \mathrm{~cm}$ high and the distance from the camera to that object was aprox. $68 \mathrm{~cm}$. 


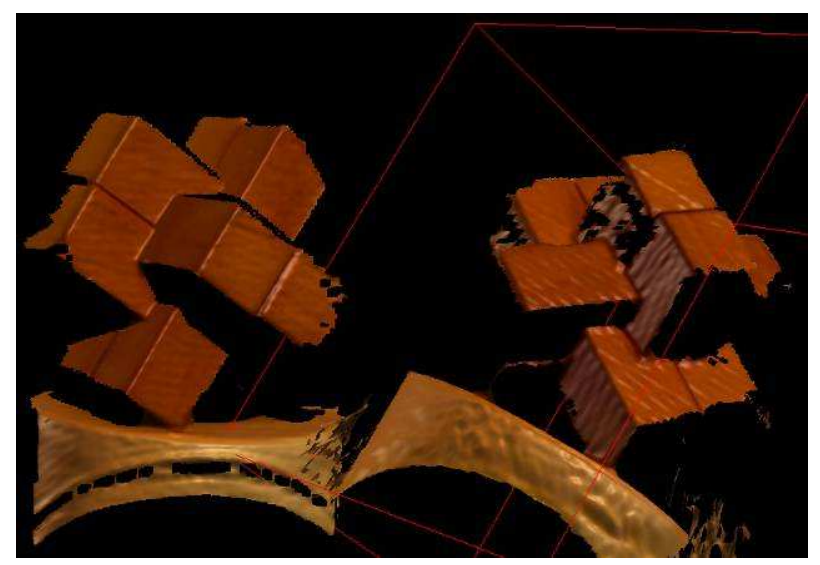

Figure 9: Fusion of 2 instances of a complex object (element of a wooden chain from Maramureș)

\subsection{Concept proof. Calibration}

The concept proof stage was important to determine if the chosen solution is fit for our project. During this stage, the first experiments were done, allowing us to understand both the principles and also the limits of this system.

Different mechanisms were tested in order to obtain the required smoothness of the movement of the laser plane. The first solution was a DC motor with reduction gear. At present, we are developing a system with a micro stepping motor with a microcontroller, which will enable us to automate the scanning procedure: speed control, stop-start of laser plane, stop-start of camera, light control. This will allow us to calibrate the system according to the necessities of our work.

\section{CONCLUSIONS}

Besides other methods of 3D scanning that gained recognition, the method we are using can prove useful for 3D scanning of objects of a certain dimension. Some of its advantages are the extreme low cost and flexibility. The resolution of the reconstructed images depends mainly of the type of camera used. Basically, it allows people to build their own 3D scanner, according to their needs.

Another important advantage is that the software allows 3D processing of images and videos acquired offline if the relative position of the object, of the scanner and of the camera is known.

The alarming destruction rate of the small wooden churches is offering us, paradoxically, the motivation to continue with the endeavour. Our project aims at restoring these bridges of transcending represented by the imperial gates, but their restoration will also determine a restoration of our way of relating to the transcendent.

\section{REFERENCES}

Baboș, A., (2004). Tracing a Sacred Building Tradition, Wooden Churches, Carpenters and Founders in Maramures until the turn of the 18th century. Norrköping: Lunds universitet.

Cîmpian, F.E. (2002a). Bisericile de lemn din zonele Călatei, Gilăului, Hășdatelor și Clujului. Aspecte istorico-etnografice și arhitectură tradițională. Cluj Napoca, Ed. Risoprint Cluj.

Cîmpian, F.E. (2002b). Pictura și elementele decorative în bisericile de lemn din zonele Călatei, Gilăului, Hășdatelor și Clujului. Cluj Napoca, Ed. Risoprint Cluj

Florovski, G. (1994), Iconostasul, Fundaţia Anastasia, 1994.

Godea, I., Medeleanu, H. (2009). Biserici de lemn din Arad, Editura Brumar, Timișoara.

Haas, Fr., Schulcz, F. (1866). Die Holzkirchen im Bisthume Szatmár. Mitheilungen der K. K. CentralCommission zur Erforschung und Erhaltung der Baudenkmale XI: 1-14

McLaughlin. H. W. (2002). By Their Own Hands: A Year Living in Romania, in Winter 2002 Issue, New Rag Rising.

McLaughlin, K. L. (2001). A Contactful Life: The Peasants of Maramureș, Romania. Thesis, Virginia Commonwealth University, Richmond, Virginia, USA.

Mitrofan, H., Ghiță, M. (2008). Picturi murale în vechi biserici de lemn din Transilvania, ISBN 978973-7930-18-5, CIMEC, Bucarest.

Nistor, Fr. (1983). Maramureș, Țara lemnului, Editura sport-turism, București.

Pănoiu, A. (1977). Din arhitectura lemnului în România, Editura Tehnică, București.

Stăniloae, D. (2000), Introducere la Sfântul Maxim Mărturisitorul, Mistagogia, Ed. Ed. Institutului Biblic şi de Misiune al Bisericii Ortodoxe Române, Bucureşti.

Stăniloae, D. (2004), Spiritualitate şi comuniune în Liturghia ortodoxă, Ed. Institutului Biblic şi de Misiune al Bisericii Ortodoxe Române, Bucureşti.

Winkelbach, S., Molkenstruck, S., Wahl, F.M. (2006). Low-Cost Laser Range Scanner and Fast Surface Registration Approach, DAGM 2006, LNCS 4174, pp.718/728, Springer Berlin Heidelberg.

\section{ACKNOWLEDGMENTS}

Images from figures 2 and 3 should be attributed under Creative Commons Attribution 2.5 to Țetcu Mircea Rareș. 